\title{
縦隔原発絨毛上皮癌の一例
}

\section{Primary Mediastinal Choriocarcinoma in a Male}

増田秀雄・尾形利郎・菊地敬一・高木啓吾・河合俊明*・中西邦明*

要旨：縦隔の絨毛上皮癌は性腺原発を否定された症例がacceptable caseとされ, 若年男子に多 く発症し大変予後の悪い疾患である．29才男性の急激に増大する縦隔腫瘍に対して手術 を行い, 術後化学療法及放射線治療を併用したが全経過 9 か月で死亡した。剖検では睪 丸に原発巣は認められず，肺・肝・脳・腎に転移を認め，肺腫瘍組織中の $\beta$-hCGが 1100 $\mathrm{ng} / \mathrm{ml}$ であり縦隔原発絨毛上皮癌と診断した。

〔肺癌 26(6) :693〜698，1986〕

Key words : Choriocarcinoma, $\beta-\mathrm{hCG}$, CDDP.

\section{はじめに}

縦隔原発の絨毛上皮癌は若年男子に多く大変 子後の悪い疾患である。今回, 我々は術前に急 激な腫瘍の増大を認め手術を行い絨毛上皮癌と 診断され, 術後化学療法及び放射線治療を併用 して全経過 9 か月で死亡した症例を経験した。 germ cell originのchoriocarcinomaが縦隔に 原発することは大変稀であり, Fineら ${ }^{1)}$ acceptable caseでは睪丸を $2 \mathrm{~mm}$ blockスライスで 検討して原発巣が確認できない症例だけが縦隔 原発と評価される。我々の症例では死後剖検に より睪丸原発は否定され, 縦隔原発䋐毛上皮癌 と考之られたので報告する。

\section{症 例}

患者は29才の男性で職業は警察官である。胸 部異常影を主訴として1981年 7 月 30 日に来院し た。現病歴では同年 7 月 10 日の検診で胸部異常 影を指摘されている. 既往歴・家族歴に特別の ものはない.Fig. 1は初診時外来で撮影した胸 部X線正面像である。肺動脈弓の高さに一致し

防衛医科大学校第 2 外科

* 同 第 1 病理
て外側に突出する辺縁が鮮明な腫瘤影を認める. Fig. 2はその時の側面像で前縦隔に長径 $4.5 \mathrm{~cm}$ の腫瘍影を認める。前年度の定期検診の胸部写 真では異常を認めないことから，この 1 年間に 前縦隔に発生した腫瘍と診断し同年 8 月 19 日に 入院した. 入院時理学的所見に特別のものはな く，血液・㽷・糞便などの一般検査においても 異常を認めず, $\mathrm{LDH} \cdot \alpha$-フェトプロテイン・ CEAはいずれも正常であった. Fig. 3の胸部CT スキャンでは左前縦隔に最大径 $7.9 \mathrm{~cm}$ で辺縁明 瞭な腫瘍影を認める.a.は単純で, b.は造影剤に よる enhancementを行っているが, 腫瘍は多房 性でありそれぞれの中心は放射線透過性を示し， 周囲には造影剤のとりこみを認め腫瘍影は明ら かに増強されている. Fig. 4は左側初診時と右 側手術直前の胸部 X線写真の比較である. その 間35日で明らかに腫瘍は増大を示し, 左胸腔内 には胸水の貯留も認女る。以上の結果, 前縦隔 に発生した増大傾向の強い縦隔腫瘍として同年 9 月 7 日に手術を行った。手術は左後側方切開 で行い, 開胸時黄色透明な胸水 $400 \mathrm{ml}$ を認めた。 腫瘍は表面暗赤色で軟らかく，肺 -心囊・壁側 胸膜と強固に癒着を示した。 Fig. 5は切除標本 
Fig. 1. Chest X-ray film on admission showing left mediastinal tumor shadow.

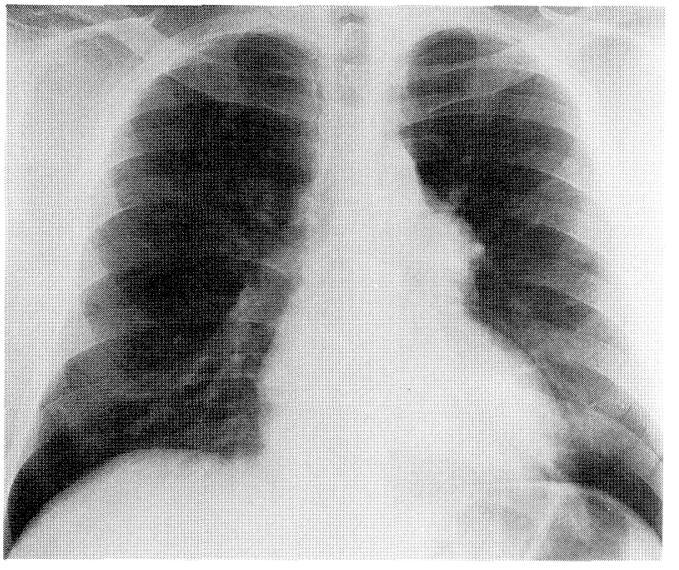

Fig. 2. Chest X-ray film (lateral view) showing upper mediastinal tumor shadow (arrow).

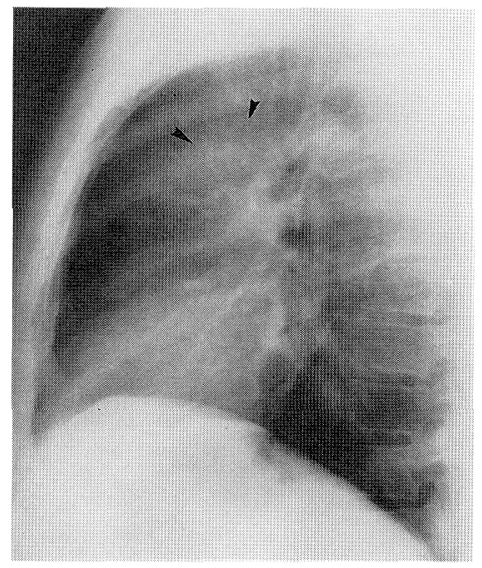

Fig. 3. Thoracic CT-scan.

(a) showing a large tumor in the left hemithorax.

(b) showing enhancement effect of the tumor with nodular cystic lesions.

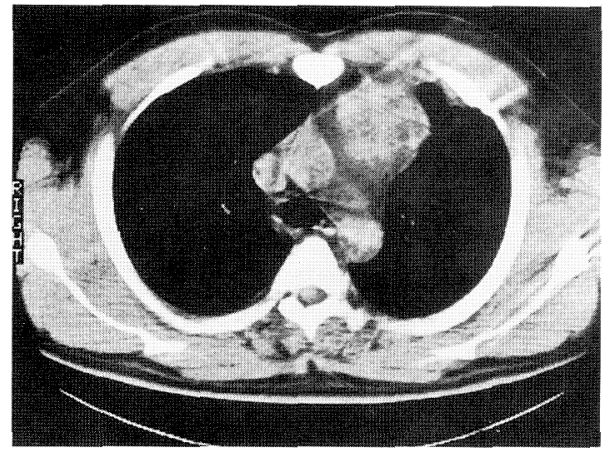

(a)

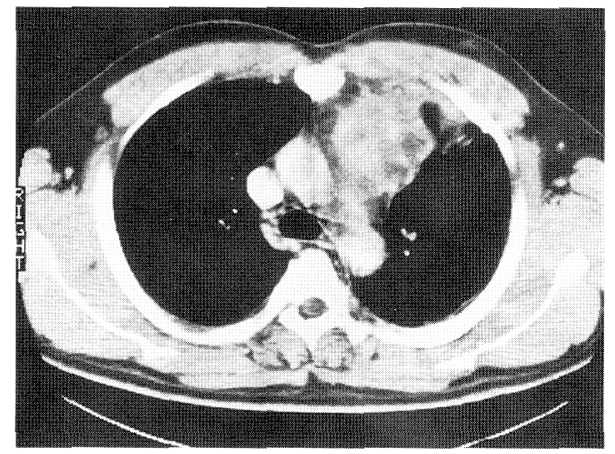

(b)

Fig. 4. Chest X-ray film.

(a) on admission and.

(b) just before the operation. The interval is 35 days.

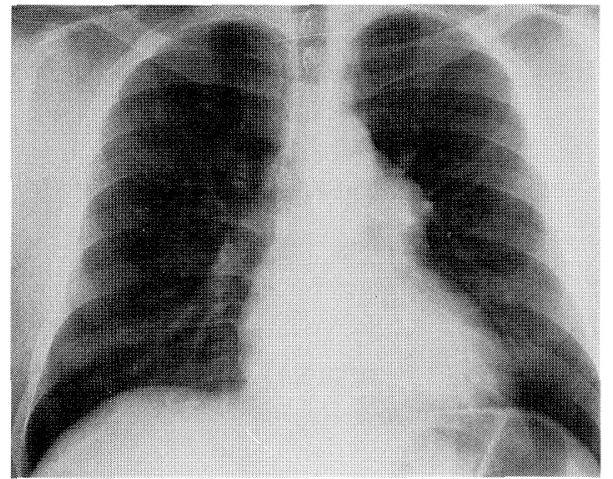

(a)

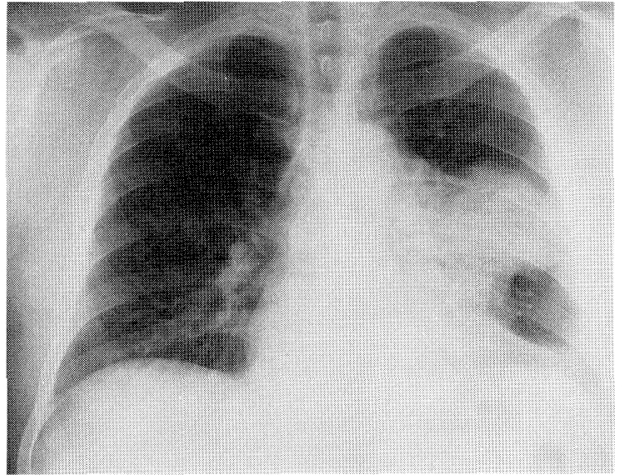

(b) 
Fig. 5. Gross finding of resected tumor. Arrows pointing the portions invading the lung.

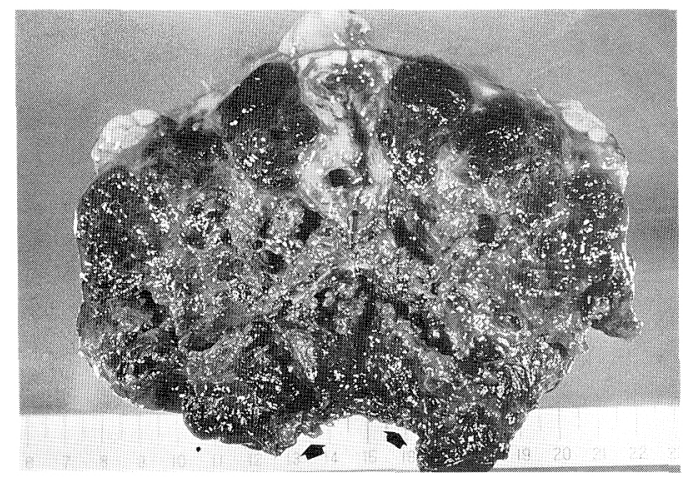

の割面を示すが，下部で被膜の破れた部分(矢 印は肺との瘾着が強く腫場を一部肺側に残し た箇所でありこれに対しては肺の部分切除を追 加して腫痗を全摘した。Fig. 6は病理標本の光 顕写真である。高度の出血を伴うtrophoblastic cellの增殖でatypy，mitosisが顕著であり choriocarcinomaの所見を示している。また，術中提 出した胸水の細胞診の結果は㓌性であった。術 後経過は良好であったが，2 日目の胸部X線写 真で右中肺野にcoin lesionの出現を認めた。こ れは後日揖影された断層写真によって転移巣上 確認された(Fig.7)。Fig. 8に術後の治療経過を 示守。診断確定後, 化学療法開始直前の血清 · 尿中hCG值はそれぞれ4229，2873mIU/mlで明 らかに高值を示していた。化学療法としては methotrexate 20mg筋注, actinomycin D 0.5 $m g$ 静注, cyclophosphamide $100 \mathrm{mg}$ 静注の投与 を 5 日間連続し，10日間の休薬期間を掞いてく クかえすMAC療法を行った。3クール目からは methotrexateのみを25mgに増量した。血清・尿 中hCG值は著明な低下を認めて 3 クール目開始 直前の值はそれぞれ $280 ， 170 \mathrm{mIU} / \mathrm{ml}$ であった。 その後，11月 9 日の血清 $\mathrm{hCG}$ 值は $1500 \mathrm{mIU} / \mathrm{ml}$ と再上昇を示したため，11/10～11/14及び11/ 24 11/28の 2 クールを追加してMAC療法は 5 クールで終了した。その後縦隔再発・肺内転移 を認めたために1/26〜2/17の間縦隔に3200 rad， 2/19 - 3/17左肺に 4000 radの放射線治療を行っ
Fig. 6. Histological picture of the tumor revealing choriocarcinoma.

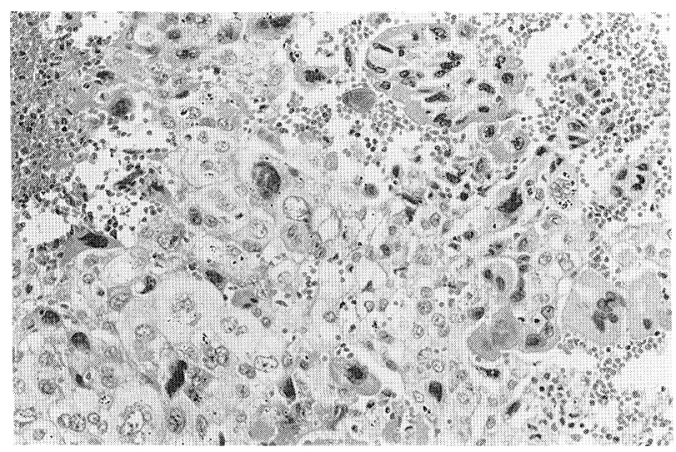

Fig. 7. Post operative chest X-ray tomograph showing metastasis in the right lung.

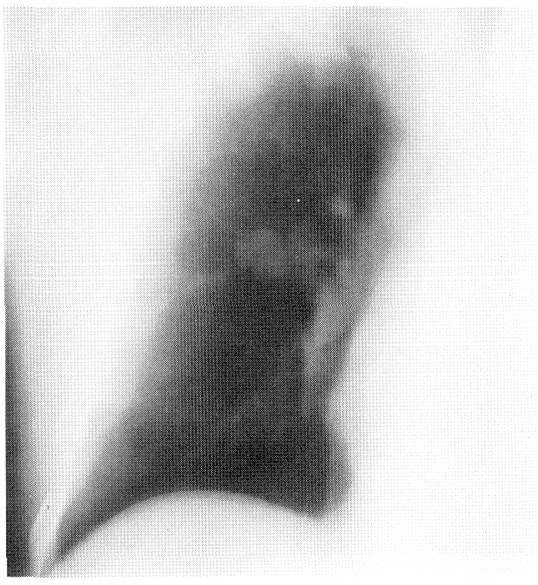

た。また，化学療法は1981年12月8日からcisplatin $(30 \mathrm{mg} /$ day, days $1 \sim 5)$, vinblastine (15 $\mathrm{mg} /$ day, days1.2.), bleomycin (30 mg/ day, days2.9.16.21.) に変更して1982年 1 月 5 日， 2 月 2 日， 3 月 2 日の計 4 クール施行した。 この間, 2 クール終了後hCG值は1/25で血清・ 尿中でそれぞれ $500,350 \mathrm{mIU} / \mathrm{ml}$ まで低下を示 したが $2 / 1$ には血清 $\mathrm{hCG}$ 值は $2300 \mathrm{mIU} / \mathrm{ml}$ と再 上昇を認脄。患者は化学療法に伴う造血器障 害のため新鮮血の輸血を必要としたが, performance statusは良好であり1982年 3 月30日に 一時退院した。外来ではvinblastine $10 \mathrm{mg}$ 静注 の投与老 $3 / 30 \cdot 4 / 1,4 / 26 \cdot 4 / 27$ の両日に行っ た。患者は復職して通院治療を受けていたが, 
Fig. 8. Postoperative course.

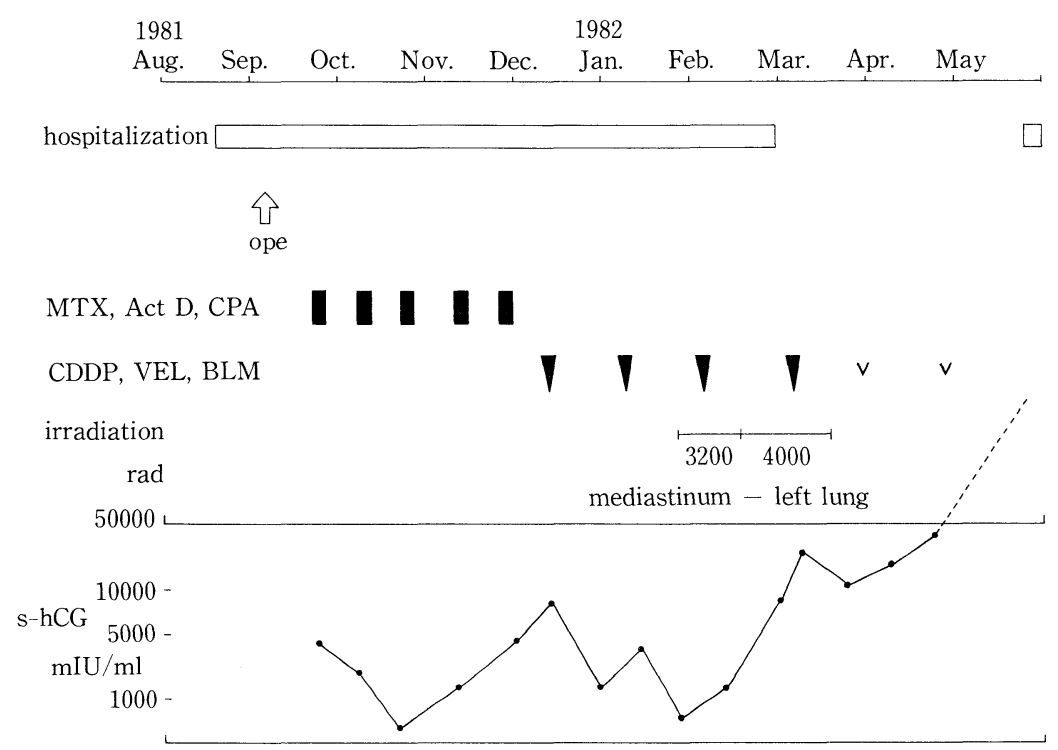

5/15に温泉に出かけた際に血痰・呼吸苦を生じ てから症状増悪して $5 / 24$ に再入院した. 入院時 すでに呼吸不全の状態であり，その後気管内挿 管下にレスピレーターによる呼吸管理を行った が5/30・術後 9 か月目に死亡した。剖検の結果, 直接死因は多発肺内転移及び肺梘血水腫に上る 呼吸不全であった。転移は両側肺に多発性に認 められる他に, 肝左葉・左後頭葉・左腎に認女 られた。さらに精巣は左 $15 \mathrm{gm}$, 右 $16 \mathrm{gm}$ と萎縮を 認めたが $2 \mathrm{~mm}$ スイスの連続切片上で原発巣 と思われる病巣は確認されなかった。また，腫 瘍組織中の $\mathrm{hCG}$ は 10 万 $\mathrm{mIU} / \mathrm{ml}$ 以上であり $\beta-$ $\mathrm{hCG}$ 己 $1100 \mathrm{ng} / \mathrm{ml}$ と高值を示していた。

\section{考察}

縦隔原発の絨毛上皮癌と報告された症例のう ち，睪丸原発が否定された症例は少なくFine ら 10109 例の性腺外絨毛上皮癌の検討では純 型の絨毛上皮癌と認められたaccetable caseは 僅か 4 例だけである。その予後は非常に悪く, 斉藤ら ${ }^{2)}$ )本邦29例の検討 (睪丸原発の検索が なされていない症例もふくむ)では平均で 2 〜 3 か月死亡であり，1年以上の生存は僅かに
3 例にすぎない. 予後不良の原因としては早期 に血行性転移を来すこと，および腫痬に対する immunological rejectionが期待されないこと施 などが考えられている。Martiniら ${ }^{4)}$ は絨毛上皮 癌の 1 例で手術十化学療法十放射線治療で17か 月生存を報告している。しかし，このように 1 年以上の生存をえられた症例は稀であり，とく に手術および放射線治療による局所治療での治 癒は困難であり早期の積極的な化学療法が生存 率を改善させるものと考えられる。実際，本症 例では術後早期に肺内転移巣の出現をみたが, methotrexate $\cdot$ actinomycin $\mathrm{D} \cdot$ cyclophosphamide (MAC) おょざ゙cisplatin・vinblastine • bleo$\operatorname{mycin}(\mathrm{PVB})$ による化学療法を行い $\mathrm{hCG}$ の值 は尿中で $170 \mathrm{mIU} / \mathrm{ml}$ と下降を示したが完全寛 解には至らず，術後 9 か月目に死亡しておりそ の死因は肺・肝・脳・腎の遠隔転移による腫瘍 死であった。したがって，縦隔腫瘍においては 最毛悪性度の高い絨毛上皮癌の予後を改善子る ためには遠隔転移が起るまえにいかに早期発見 をして確定診断を得るかであり，この点では発 育進展の速い縦隔腫瘍においてはhCGの定量が 不可久であると考えられる。横沢ら ${ }^{5)}$ は血胸を 
伴うような絨毛上皮腫に対して肺の部分切除を 伴う腫瘍摘出術を行い術後actinomycin D単独 の化学療法を行い 5 年生存を報告している。こ の症例は病理学的に䄉毛上皮腫と奇形腫と診断 されておりDixon-Moore ${ }^{6)}$ の分類のTypeIVに属 し我々の症例のような純型の絨毛上皮癌とは組 織学的に異なるものであるが, 理論的には遠隔 転移を伴わない症例では当然手術による局所根 治性が期待されるわけで, 術後のhCGをマーカ 一とした積極的な化学療法との組合せが治療法 として最も合理性があるものと考えられる。す なわち, 画像診断上原発巣が胸腔内諸臓器に広 汎な浸潤を示さず局所にとどまっている場合に は導入療法として手術が有用であると考える. また，一般に絨毛上皮癌は放射線感受性に乏し く局所療法としての手術の有用性が確認されて いる報告が散見される。とくに，先のMartini ら"の報告では原発巣の切除後に肺の転移巣に 対する追加切除を行った長期生存例があり, 斉 藤ら 2 の報告でも原発巣切除後化学療法施行中 に肺転移巣の切除を行って初回術後15か月生存 の成績を報告している。また，Martiniら (4)は非 セミノ一マ型胚細胞性腫瘍の特徵は局所再発死
であると報告している。これらのことから，他 に大きな転移巣がない単独の肺転移に対しては 手術療法の検討がなされるべきであると考えら れる。絨毛上皮癌に対する化学療法としては MACによる 3 剂併用療法が有効であると報告 されているが, 本症例においては耐性の出現を 認めたためにPVBの 3 剂併用療法への変更を 行った ${ }^{8)}$. Schlaerthら ${ }^{9}$ は同様にMAC療法に対 して抵抗性を示した 2 例に対してPVB療法を 行い宽解を得たと報告している。元来，緁毛上 皮癌に対してはMAC療法が大変有効であり第 1 選択の治療法と考之られるが，今後抵抗性を 獲得した絨毛上皮癌に対してはcisplatinを中心 とした多剤併用療法に期待がもたれるものと考 えられる ${ }^{10)}$.

\section{おわりに}

全経過 9 か月の絨毛上皮癌症例の診断と治療 について文献的考察を加えて報告した。

本症例の概略を第72回肺癌学会関東部会において発 表した。

\section{文 献}

1) Fine, G., Smith, R.W. Jr., Pachter, M.R. : Primary extragenital choriocarcinoma in the male subject. Am. J. Medicine, Vol. 32, 776 -794, 1962.

2）斉藤幸人, 大迫 努, 辰巳明利, 他：原発性縦 隔未分化胚細胞性腫瘍の治療経験。日本胸外会 誌, 33：2，247-254， 1985.

3）中井祐之, 香坂茂美, 石川忠夫, 他：GonadotropinとEstrogenの産生を証明された縦隔絨毛上 皮腫の 1 例。医学のあゆみ，96(6)：458-466, 1976.

4) Martini, N., Golbey, R.B., Hajdu, S.I., et al. : Primary mediastinal germ cell tumors. Cancer, 33(3): 763-769, 1974.

5）横沢忠夫, 田中 誠, 小林 稔, 他: 原発性縦 隔絨毛上皮腫の長期生存の 1 例. 胸部外科, 35(5) : 388-391, 1982.
6) Dixon, F.J., Moore, R.A. : Testicular tumors. A clinicopathological study. Cancer, $6: 427$ $-454,1953$.

7) Goldstein, D.P., Piro, A.N. : Combined chemotherapy in the treatment of germ cell tumors containing choriocarcinoma in males and females. Surg. Gynecol. Obstet, 134 : 61, 1972.

8) Einhorn, L.H., Donohue, J. : Cis-Diamminedichloroplatinum, Vinblastin and Bleomycin combination chemotherapy in disseminated testicular cancer. An. Int. Med., 87 : 293298, 1977.

9) Schlaerth, J.B., Morrow, C.P., DePetrillo, A. D. : Sustained remission of choriocarcinoma with cis-platinum, vinblastin, and bleomycin after failure of conventional combination 
drug chemotherapy. Am. J. Obstet. Gynecol, 136 (8): 983-985, 1980.

10) Newlands, E.S., Bagshawe, K.D. : Activity of high-dose cis-platinum in combination with vincristine and methotrexate in drug-resistanat gestational choriocarcinoma. A report of 17 cases. Br. J. Cancer, 40:943-945, 1979.

（原稿受付 1985 年10月19日／採択１985年12月18日）

\title{
Primary Mediastinal Choriocarcinoma in a Male
}

\section{Hideo Masuda, Toshiro Ogata, Keïchi Kikuchi, Keigo Takagi Toshiaki Kawai* and Kuniaki Nakanishi*.}

\author{
Second Department of Surgery and First Department of Pathology* \\ National Defence Medical College.
}

The diagnosis of primary mediastinal choriocarcinoma is acceptable only when the primary site in the germinal organ has been ruled out. It appears mostly in young male patients and its prognosis is usually very poor. Recently, we operated on a 29-year old man with a rapidly growing mediastinal tumor. The patient died 9 months postoperatively while on adjuvant chemotherapy and irradiation. Autopsy disclosed no primary focus in the serially cut sections of the testes, but metastases in the lung, liver, brain and kidney were found. Titer of $\beta$-hCG reached a very high level of $1100 \mathrm{ng} / \mathrm{ml}$ in the tumor. It was thus histologically diagnosed as a primary mediastinal choriocarcinoma. 